\title{
Repurposing of Drugs Targeted Against COVID-19 Spike Receptor for Treatment: An In silico Approach
}

\author{
Souzia Shaik $^{1}$, Ranjani Soundhararajan ${ }^{1}$ (D), Hemalatha Srinivasan 1,*iD \\ 1 School of Life Sciences, B. S. Abdur Rahman Crescent Institute of Science and Technology, Vandalur, India \\ * Correspondence: hemalatha.sls@bsauniv.ac.in;
}

Scopus Author ID 56895829300

Received: 4.01.2021; Revised: 7.02.2021; Accepted: 10.02.2021; Published: 15.02.2021

\begin{abstract}
An escalating pandemic by the novel SARS-CoV2 is spreading across the globe at a rate. An urgent need for therapy is needed. Initially, the virus appeared first in Wuhan, China, and later approximately in 187 countries worldwide. Coronaviruses are causative of respiratory as well as neurological diseases in humans. The novel zoonotic disease-causing coronaviruses are single-stranded RNA viruses. The coronavirus's outer structure consists of spike protein made up of glycoproteins, which binds to ACE (Angiotensin Converting Enzyme) protein when infected in humans. In the current study, 37 compounds that are already used in the biological field as anti-viral compounds are observed with bioinformatics tools. The repurposing drugs are docked against the spike receptor by molecular Docking. The ligand structure and the receptor structure are retrieved from Protein Data Bank. Patch dock server is an open freeware available for docking procedures. The results include acceleration and score of matched properties showing the feasibility of working the drug against SARS-nCoV. For the visualization of the final docked product, PyMOL and RasWin software's are used. The scores of each ligand docked against the receptor show the compatibility working against the COVID-19 disease.
\end{abstract}

Keywords: bioinformatics; Angiotensin Converting Enzyme; glycoproteins; Patch Dock; PyMoL; zoonotic.

(C) 2021 by the authors. This article is an open-access article distributed under the terms and conditions of the Creative Commons Attribution (CC BY) license (https://creativecommons.org/licenses/by/4.0/).

\section{Introduction}

The third zoonotic coronavirus outbreak is spreading at a rate in the human population [1]. This virus was initially identified in Wuhan, China, from the Hunan Seafood market, where it got transmitted to humans by animals. The origin of the virus outbreak is still controversial. Scientists previously suspected that this virus was originated from bats; later on, they hopped on another animal named pangolin, which was proved false. Generally, coronaviruses are identified in bats, mice, rats, camels, dogs, snakes, swine's, etc. The first case was reported in a 55-year-old individual from Hubei province in early December [2]. In December, it was confirmed that a new strain of coronavirus had been evolved. By the end of December, the virus has spread in almost 400-500 individuals. According to WHO (World Health Organisation) and CDC (Centre for Disease Control), they named the virus as Novel Coronavirus-2019 (19n-CoV), and the disease caused is named COVID-19 [3]. Also, sources state that this new virus has a similarity up to $75-80 \%$ compared to SARS-CoV and other bat coronaviruses $[4,5]$.

The SARS-CoV2 has 14 binding site slits in which 8 amino acids are said to be directed, similar to novel coronavirus. One important note is that this virus has direct interaction with Angiotensin-Converting Enzyme-2 (ACE-2) [5, 6]. Coronaviruses are respiratory as well as 
neurological diseases in humans and cause SARS-CoV and MERS-CoV. Coronaviruses are said to be non-segmented encompassed with single positive-sense strand RNA viruses affiliated with the family Coronaviridae, order Nidovirales [3, 7]. The novel coronavirus has 3000 nucleotides sequences with 30kb length knowing to be the largest RNA viruses [7].

The transmission rate of the coronavirus is now catastrophic for the entire world, and health professionals suggested certain methods of prevention such as patients who got infected should be quarantined, combative testing and fast diagnosis of suspected patients, proper use of mask and using the appropriate mask (for example N95 mask) and washing hands for at least 20 seconds frequently [8]. Currently, there is no vaccine or drug available for inhibiting the transmission routes. The researchers are scoping on repurposing drugs existing, such as Nucleoside cognate and HIV protease inhibitors, which give a successive treatment methodology [8-14]. The feasible drug targets of COVID-19 are Angiotensin Converting Enzyme-2 (ACE-2) and RNA-dependent RNA polymerase (RdRp) [15-17]. Some anti-viral drugs such as favipiravir, lopinavir, remedsivir, ritonavir, Ivermectin, Oseltamivir, Ganciclovir, Chloroquine are tested against COVID-19 infection and found out to be effective [15, 18-20].

Until there is an accurate vaccine or drug, the use of previously determined, anti-viral drugs is used for treatment [21-24]. In this study, molecular docking analysis was observed in the binding site of the COVID-19 receptor and finding out the possible compound/molecule which can cope with the life-threatening coronavirus disease.

\section{Materials and Methods}

\subsection{Scaffolding for molecular docking.}

The bioinformatics survey was achieved with Patch Dock Server (Molecular Docking Algorithm Based on Shape Complementarily Principles). Patch Dock is an innovation for molecular Docking. The compute must be 2 molecules/compounds of any category such as proteins, drugs, peptides, or DNA. The profit is a list of capable complexes cataloged by shape complementarity standard [4].

\subsection{Ligand preparation.}

A total of 37 anti-viral agents from anti-viral chemotherapy from the 1960s to presentday in analytical trials were preferred for molecular Docking to visualize and to describe the dominant anti-viral compound categorically for COVID-19 treatment (table 1). Protein Data Bank and the PubChem database were used to cite the working 3D chemical structure of the anti-viral molecule/compounds selected, respectively. The molecules retrieved from the PubChem database are initially in the form of "sdf.format". These molecules are converted into "pdb.format" by using file converter software know as Open Babel.

Table 1. List of anti-viral agents docked against COVID-19 spike receptor [1].

\begin{tabular}{l|l|l|l|l} 
S.No & Name & Structure & Active against & Mechanism \\
\hline 1 & Abacavir & & & \\
& & &
\end{tabular}




\begin{tabular}{|c|c|c|c|c|}
\hline S.No & Name & Structure & Active against & Mechanism \\
\hline 2 & Acyclovir & & $\begin{array}{l}\text { herpes simplex virus } \\
\text { infections, chickenpox, and } \\
\text { shingles }\end{array}$ & $\begin{array}{l}\text { inhibits and inactivates HSV- } \\
\text { specified DNA polymerases }\end{array}$ \\
\hline 3 & Anisomycin & & Protein kinases & $\begin{array}{l}\text { Inhibits eukaryotic protein } \\
\text { synthesis }\end{array}$ \\
\hline 4 & Azithromycin & & Bacterial infections & Inhibits translation of mRNA \\
\hline 5 & Cepharanthine & & $\begin{array}{lr}\text { HTLV } & \text { (Human } \\
\text { Lymphocytes virus) }\end{array}$ & $\begin{array}{l}\text { Inhibits IFN-r- induced CXCL10 } \\
\text { production in NS-SV-DC cells }\end{array}$ \\
\hline 6 & Chrysin & & Anaphylaxis & $\begin{array}{l}\text { Inhibits myosin light chain } \\
\text { kinase }\end{array}$ \\
\hline 7 & Colchicine & & gout and Behçet's disease & $\begin{array}{l}\text { Inhibits microtubule production, } \\
\text { activation of neutrophil and } \\
\text { super anion oxide }\end{array}$ \\
\hline 8 & Cyanovirin & 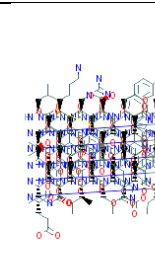 & HIV, Influenza & $\begin{array}{l}\text { Inhibits binding of mucosal cell } \\
\text { surfaces }\end{array}$ \\
\hline 9 & Daidzin & & Antidipsotropic & Inhibits aldehyde dehydrogenase \\
\hline
\end{tabular}




\begin{tabular}{|c|c|c|c|c|}
\hline S.No & Name & Structure & Active against & Mechanism \\
\hline 10 & Emetine & & Vomiting & Inhibits DNA replication \\
\hline 11 & Emodine & & $\begin{array}{l}\text { Antibacterial, } \\
\text { inflammatory, and anti- } \\
\text { viral activities }\end{array}$ & $\begin{array}{l}\text { Inhibits 3a protein in SARS- } \\
\text { CoV2 }\end{array}$ \\
\hline 12 & Fangchinoline & & Anti-cancer activity & Inhibits apoptosis \\
\hline 13 & Favipiravir & & Influenza & $\begin{array}{l}\text { inhibition of viral RNA- } \\
\text { dependent RNA polymerase }\end{array}$ \\
\hline 14 & Fingolimod & & $\begin{array}{l}\text { chronic inflammatory } \\
\text { demyelinating } \\
\text { polyneuropathy }\end{array}$ & internalization of S1P receptors \\
\hline 15 & Ferruginol & & Anti-tumor properties & Inhibit the growth of tumor \\
\hline 16 & Hydroxychloroquine & & $\begin{array}{l}\text { Treatment for malaria, } \\
\text { rheumatoid arthritis, lupus, } \\
\text { and porphyria cutanea } \\
\text { tarda }\end{array}$ & $\begin{array}{l}\text { inhibition of hemozoin bio } \\
\text { crystallization }\end{array}$ \\
\hline 17 & Interferon beta & & $\begin{array}{l}\text { Treatment of multiple } \\
\text { sclerosis }\end{array}$ & $\begin{array}{l}\text { Inhibition of inflammatory cells } \\
\text { across a blood-brain carrier }\end{array}$ \\
\hline
\end{tabular}




\begin{tabular}{|c|c|c|c|c|}
\hline S.No & Name & Structure & Active against & Mechanism \\
\hline 18 & Ivermectin & & $\begin{array}{l}\text { Treatment for many types } \\
\text { of parasite infestations, } \\
\text { SARS-CoV2 }\end{array}$ & $\begin{array}{l}\text { Increases parasite permeability } \\
\text { causing paralysis, and then cell } \\
\text { death inhibits viral replication }\end{array}$ \\
\hline 19 & Kazinol & & $\begin{array}{l}\text { Treatment } \\
\text { melanogenesis }\end{array}$ & $\begin{array}{l}\text { Inhibits melanogenesis, } \\
\text { tyrosinase }\end{array}$ \\
\hline 20 & Lopinavir & & HIV infections & Inhibits protease \\
\hline 21 & Luteolin & & $\begin{array}{l}\text { Inflammatory agent and } \\
\text { immune system modulator } \\
\text { for several cancers }\end{array}$ & Inhibits pgd2 \\
\hline 22 & Marinostatin & & $\begin{array}{l}\text { Treatment } \\
\text { neuroendocrine tumors }\end{array}$ & Inhibits unique protein protease \\
\hline 23 & $\begin{array}{l}\text { Mycophenolate } \\
\text { mofetil }\end{array}$ & & $\begin{array}{l}\text { Treatment of Crohn's } \\
\text { disease }\end{array}$ & $\begin{array}{l}\text { Non-competitive inhibitor of } \\
\text { inosine-5'-monophosphate } \\
\text { dehydrogenase }\end{array}$ \\
\hline 24 & Oseltamivir & & $\begin{array}{l}\text { treat and prevent influenza } \\
\mathrm{A} \text { and influenza B }\end{array}$ & neuraminidase inhibitor \\
\hline 25 & Phenazopyridine & & $\begin{array}{l}\text { Treatment for urinary tract } \\
\text { infections, surgery, or } \\
\text { injury to the urinary tract }\end{array}$ & Inhibition not well known yet \\
\hline
\end{tabular}




\begin{tabular}{|c|c|c|c|c|}
\hline S.No & Name & Structure & Active against & Mechanism \\
\hline 26 & Quercetin & & Treatment of cancer & Inhibits natural pgd2 \\
\hline 27 & Ribavirin & & $\begin{array}{l}\text { Treatment for RSV } \\
\text { infection, hepatitis C and } \\
\text { some viral hemorrhagic } \\
\text { fevers. }\end{array}$ & Inhibits nucleosides \\
\hline 28 & Ritonavir & & Treatment for HIV/AIDS & inhibitor of HIV protease \\
\hline 29 & Remedsivir & & $\begin{array}{l}\text { specific treatment for } \\
\text { COVID-19, hepatitis } \\
\text { Ebola, Marburg virus }\end{array}$ & Inhibits viral replication \\
\hline 30 & Resveratrol & & $\begin{array}{l}\text { Treatment for heart } \\
\text { diseases, cancer, diabetes }\end{array}$ & Inhibits NF-kB Signalling \\
\hline 31 & Saikosaponins C & & Treatment for SARS-CoV2 & $\begin{array}{l}\text { inhibits lipopolysaccharide- } \\
\text { induced apoptosis }\end{array}$ \\
\hline 32 & Saikosaponins D & & Treatment of cancer & Inhibits osteoclast genesis \\
\hline 33 & Silvestrol & & $\begin{array}{l}\text { Treatment for Ebola, } \\
\text { coronaviruses, and cancer } \\
\text { properties }\end{array}$ & $\begin{array}{l}\text { Selective inhibitor of the RNA } \\
\text { helicase enzyme eIF4A }\end{array}$ \\
\hline
\end{tabular}




\begin{tabular}{|c|c|c|c|c|}
\hline S.No & Name & Structure & Active against & Mechanism \\
\hline 34 & Tannic acid & & $\begin{array}{l}\text { Treatment for prostate } \\
\text { cancer }\end{array}$ & Inhibits lipid metabolism \\
\hline 35 & Tanshinone & & $\begin{array}{l}\text { Treatment for oesophageal } \\
\text { cancer }\end{array}$ & $\begin{array}{l}\text { Inhibits growth and metastasis of } \\
\text { osteosarcoma }\end{array}$ \\
\hline 36 & Tylophorine & & Treatment for lung cancer & $\begin{array}{l}\text { Inhibits Akt and } \mathrm{NF}-\mathrm{kB} \\
\text { pathways }\end{array}$ \\
\hline 37 & Valganciclovir & & $\begin{array}{l}\text { Treatment } \\
\text { for } \\
\text { cytomegalovirus (CMV) } \\
\text { infection in those with } \\
\text { HIV/AIDS }\end{array}$ & $\begin{array}{l}\text { Inhibits human adenovirus } \\
\text { replication }\end{array}$ \\
\hline
\end{tabular}

For docking studies, the receptor and the ligand of the interest should be in "pdb.format". The molecules retrieved from Protein Data Bank are already in "pdb.format" so conversion is unnecessary $[25,26]$.

\subsection{Preparation of spike receptor and framework generation.}

To encounter the present locus of COVID-19 spike receptor of novel coronavirus that is the spike Glycoprotein (PBD ID: 6VSB having a resolution of 3.46A', Aggregation State: particle, Reconstruction Method: Single Particle) were tabbed from the website Protein Data Bank (www.rscb.org) with good resolution of the structure. The receptor's total structural weight is $440.69 \mathrm{kDa}$ consisting of 22854 atomic counts, 2905 residue counts, and has 1 unique protein chain. The spike protein Glycoprotein Chain A, B, C has a sequence length of 1288 with five mutations $[27,28]$.

\subsection{Molecular docking.}

Molecular Docking is a period used to develop structure-based drug design because of its capability to anticipate the binding conformation to small-molecule ligands to the allot receptor. The synergy of ligands is visualized by enumerating action, which predicts the receptor molecule's binding capacity [29-33]. Patch Dock Server is used in this study, where the receptor and the ligand file formats are uploaded. Since it is an online freeware, the results will be directed to the mail address given. The clustering RMSD is set at 4.0 with the default complex type. 


\section{Results and Discussion}

The purpose of seeking standard strategy treatment for COVID 19, molecular Docking is performed against 37 selected molecules showing anti-viral activity with the binding of spike protein Glycoprotein of COVID19 (PBD ID: 6M17) (Figure 1) [34]. Some of these molecules are under clinical trials, and others are used to treat various diseases. Most of the molecules selected are active against diseases such as HIV, Hepatitis C, Tumours, Cancer, Ebola, Cytomegalovirus, and Influenza [3, 35-38]. The appliance of these compounds is also particular such as DNA polymerase, protease inhibition, and inhibition of reverse transcriptase etc. [27, $39,40]$. The account of drugs that are tested for docking study is portrayed in table 1.

The compound Abacavir (PBD ID: 5U98) showed an overall score of 18958, covering an area of 2885.10 with ACE value of -60.92. The compound Acyclovir (PBD ID: 5I3C) showed an overall score of 21434, covering an area of 4720.20 with ACE value of 414.50. The compound Anisomycin (PBD ID: 3CC4) showed an overall score of 18698 covering an area of 2815.80 with ACE value of -176.90. The compound Azithromycin (PBD ID: 5UXD) showed an overall score of 24910covering an area of 3330.50 with ACE value of 321.30. The compound Cepharanthine (PubChem CID: 10206) showed an overall score of 3294, covering an area of 367.60 with ACE value of -71.69. The compound Chrysin (PBD ID: 3EBO) showed an overall score of 21524, covering an area of 5339.90 with ACE value of 75.39. The compound Colchicine (PBD ID: 6JWE) showed an overall score of 16134, covering an area of 2138.80 with ACE value of -529.64. The compound Cyanovirin (PBD ID: 4J4E) showed an overall score of 22604, covering an area of 3792.40 with ACE value of 381.34. The compound Daidzin (PBD ID: 2VLE) showed an overall score of 16358, covering an area of 3277.80 with ACE value of 48.12. The compound Emetine (PBD ID: 3J7A) showed an overall score of 17140 , covering an area of 2588.50 with ACE value of 63.44. The compound Emodine (PubChem CID: 10207) showed an overall score of 5254, covering an area of 667.20 with ACE value of -601.74. The compound Fangchinoline (PubChem CID: 73481) showed an overall score of 5476, covering an area of 628.20 with ACE value of -365.47. The compound Favipiravir (PBD ID: 4KN6) showed an overall score of 24328, covering an area of3166.30 with ACE value of 465.16. The compound Fingolimod (PubChem CID: 107970) showed an overall score of 4334 covering an area of 507.90 with ACE value of -95.18. The compound Ferruginol (PBD ID: 5YM3) showed an overall score of 21628covering an area of 3577.90 with ACE value of -77.39. The compound Hydroxychloroquine (PBD ID: 1CET) showed an overall score of 23918, covering an area of 3881.90 with ACE value of 177.89. The compound Interferon-beta (PBD ID: 1AU1) showed an overall score of 23262, covering an area of 5430.70 with ACE value of 272.28. The compound Ivermectin (PubChem CID: 5VDI) showed an overall score of 16940, covering an area of 2725.50 with ACE value of 460.45. The compound Kazinol (PubChem CID: 184311) showed an overall score of 4908 covering an area of 543.10 with ACE value of-141.81. The compound Lopinavir (PBD ID: 4LIA) showed an overall score of 21358, covering an area of 3053.70 with ACE value of 206.16. The compound Luteolin (PubChem CID: 5280445) showed an overall score of 3750, covering an area of 414.80 with ACE value of -81.65. The compound Marinostatin (PBD ID: 1IXU) showed an overall score of 10132, covering an area of 1544.90 with ACE value of 153.62. The compound Mycophenolatemofetil (PubChem CID: 5280445) showed an overall score of 3336, covering an area of 444.50 with ACE value of -298.60. The compound Oseltamivir (PBD ID: 3CLO) showed an overall score of 21306, covering an area of 3317.70 with ACE value of 188.66. The 
compound Phenazopyridine (PubChem CID: 4756) showed an overall score of 4092, covering an area of 491.40 with ACE value of -168.79. The compound Quercetin (PBD ID: 1H1I) showed an overall score of 20394, covering an area of 4099.80 with ACE value of -534.64 . The compound Ribavirin (PBD ID: 1R6A) showed an overall score of 19118, covering an area of 3306.80 with ACE value of 460.45. The compound Ritonavir (PBD ID: 3TNE) showed an overall score of 22182, covering an area of 2990.20 with ACE value of 426.74. The compound Remedsivir (PBD ID: 7BV2) showed an overall score of 19442, covering an area of 3019.00 with ACE value of 207.83. The compound Resveratrol (PBD ID: 2L98) showed an overall score of 18508 , covering an area of 2706.80 with ACE value of 30.92. The compound Saikosaponins C (PubChem CID: 46783811) showed an overall score of 6114, covering an area of 739.30 with ACE value of -575.57. The compound Saikosaponins D (PBD ID: 2Q33) showed an overall score of 18964, covering an area of 2319.40 with ACE value of -566.36 . The compound Silvestrol (PubChem CID: 11787114) showed an overall score of 3744, covering an area of 398.30 with ACE value of -214.69. The compound Tannic acid (PBD ID: 1CBR) showed an overall score of 20426, covering an area of 3756.00 with ACE value of 158.23. The compound Tanshinone (PubChem CID: 114917) showed an overall score of 3744, covering an area of 398.30 with ACE value of -214.69. The compound Tylophorine (PubChem CID: 92114) showed an overall score of 4702, covering an area of 578.00 with ACE value of -289.23. The compound Valganciclovir (PBD ID: 6GS4) showed an overall score of 21666, covering an area of 3477.60 with ACE value of 188.55 .

Out of 37 compounds, Acyclovir, Azithromycin, Chrysin, Cyanovirin, Favipiravir, Ferruginol, Hydroxychloroquine, Interferon beta, Lopinavir, Oseltamivir, Quercetin, Ritonavir, Tannic acid, Valganciclovir is of dock score above 20,000 and were found to be more interactive with the spike protein Glycoprotein [29, 41, 42]. Other dock score compounds above 10,000 such as Abacavir, Anisomycin, Colchicine, Daidzin, Emetine, Ivermectin, Marinostatin, Ribavirin, Remedsivir, Resveratrol, Saikosaponins D were also found to be interactive with the spike protein Glycoprotein [30, 43]. Compounds with a docking score below 10,000 include Cepharanthine, Emodine, Fangchinoline, Fingolimod, Kazinol, and Luteolin Mycophenolatemofetil, Phenazopyridine, Saikosaponins C, Silvestrol, Tanshinone, and Tylophorine are found to be less interactive with the spike protein Glycoprotein [35, 22, 44]. The docking images were depicted in figure 1 (1-37) for all 37 compounds. The final outputs of docked compounds are listed in table 2.

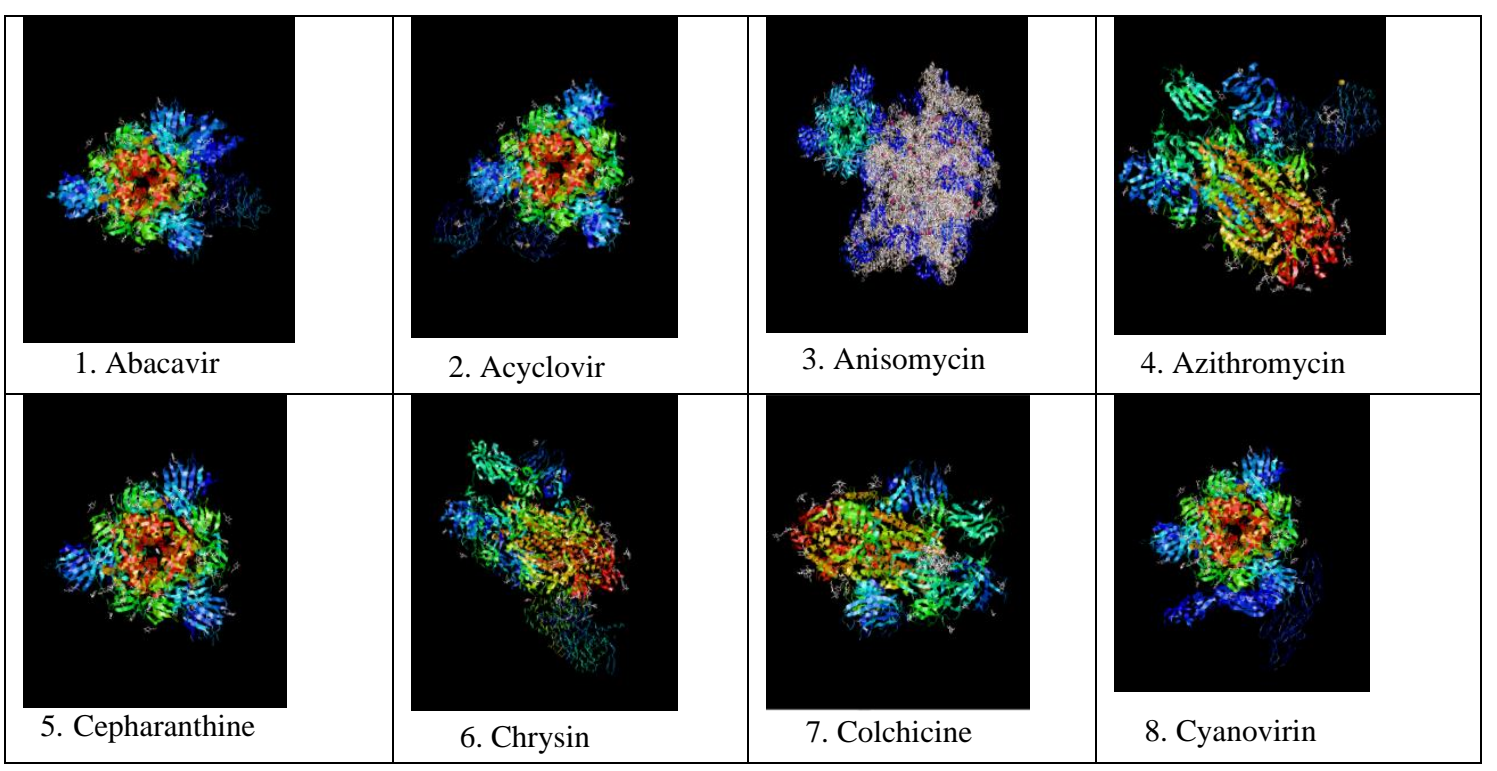

https://biointerfaceresearch.com/ 

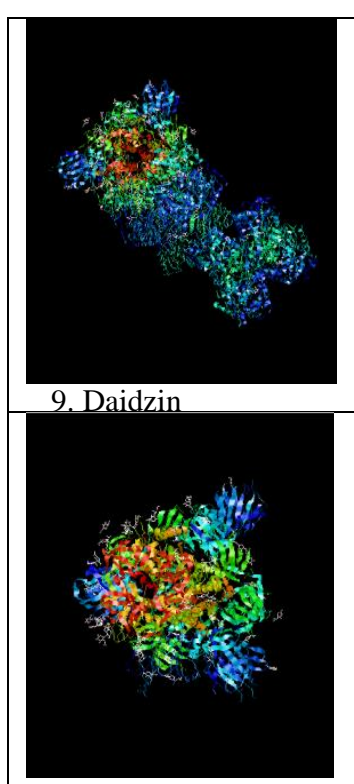

13. Favipiravir

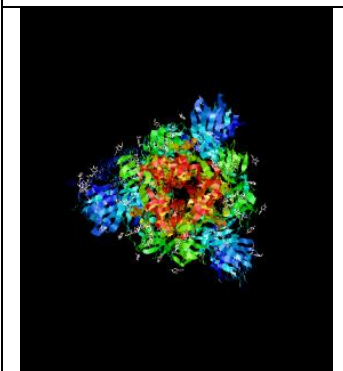

17. Interferon beta

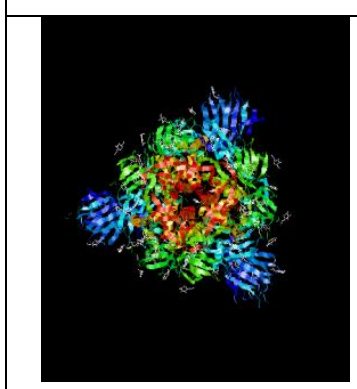

21. Luteolin

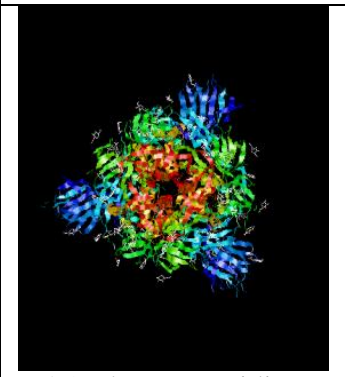

25. Phenazopyridine

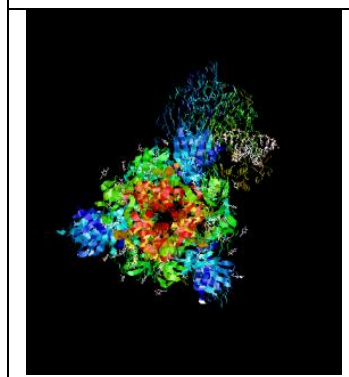

29. Remedsivir

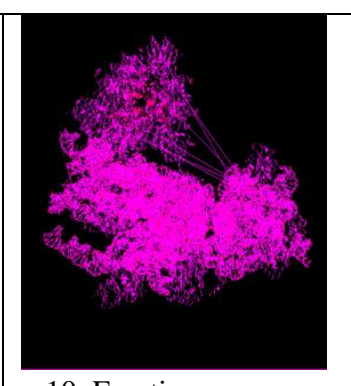

10. Emetine

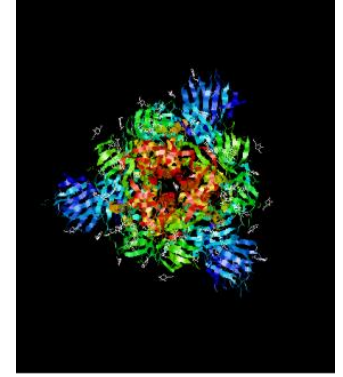

14. Fingolimod

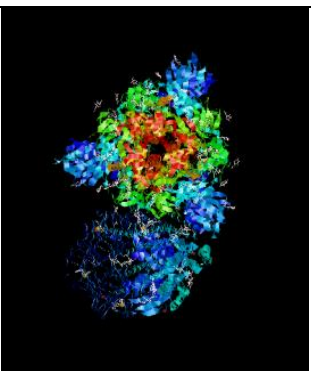

18. Ivermectin

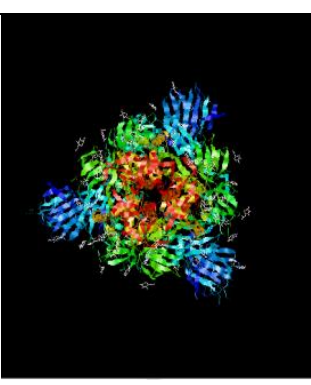

22. Marinostatin

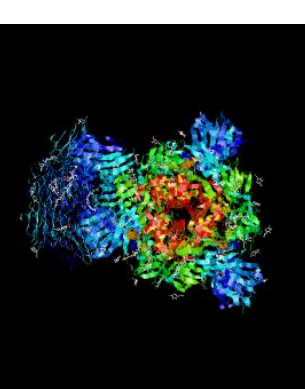

26. Quercetin

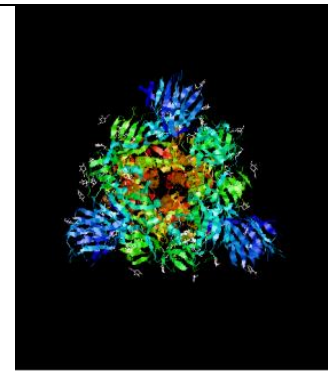

30. Resveratrol
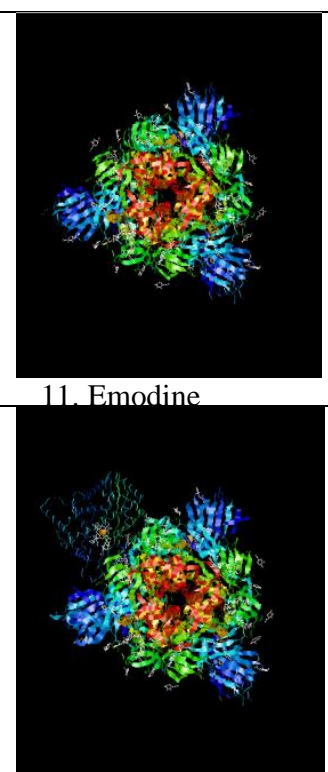

15. Ferruginol

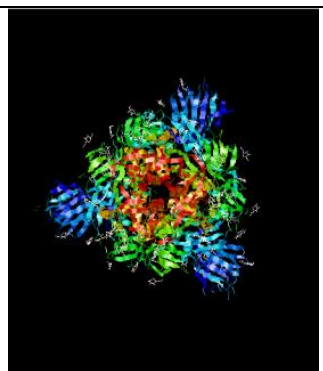

19. Kazinol

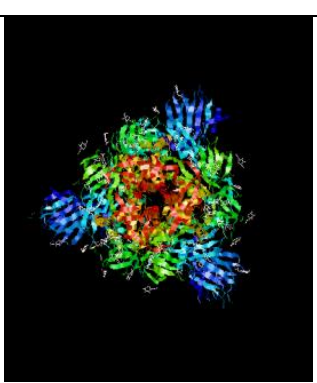

23. Mycophenol-

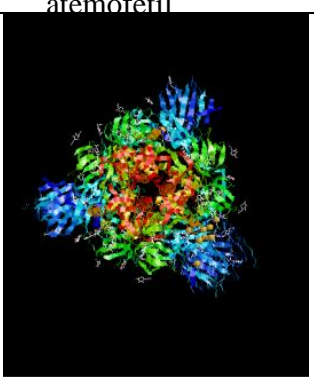

27. Ribavirin

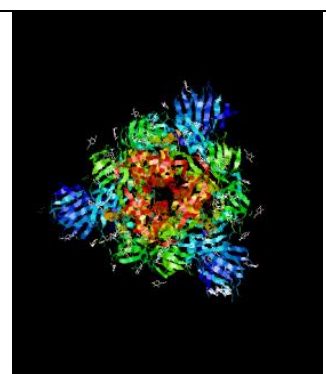

31. Saikosaponins C

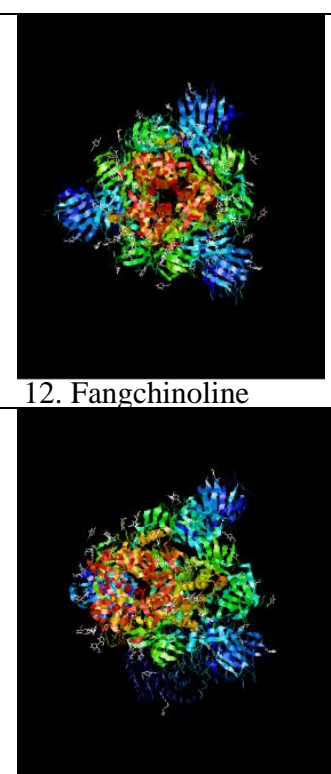

16. Hydroxychloroquine

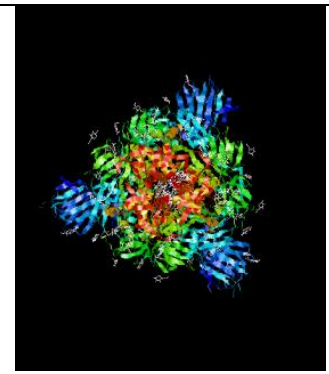

20. Lopinavir

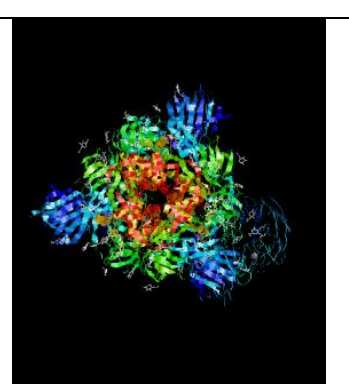

24. Oseltamivir

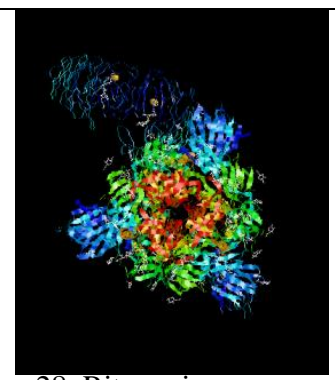

28. Ritonavir

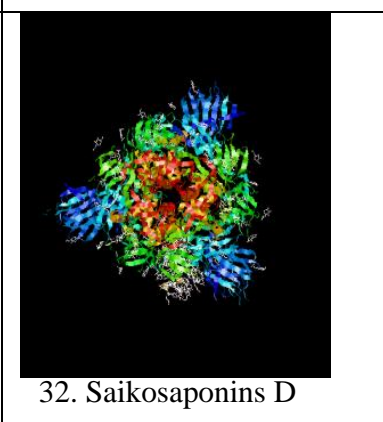




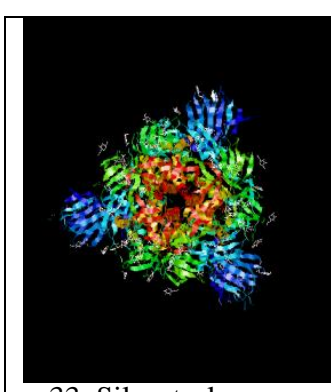

33. Silvestrol

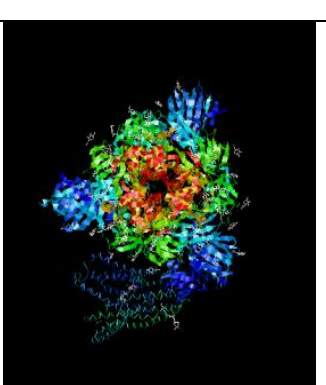

37. Valganciclovir

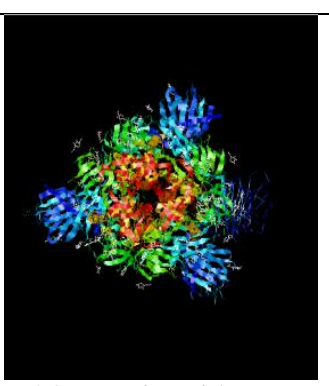

34. Tannic acid

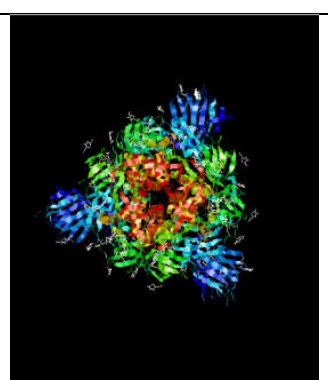

35. Tanshinone

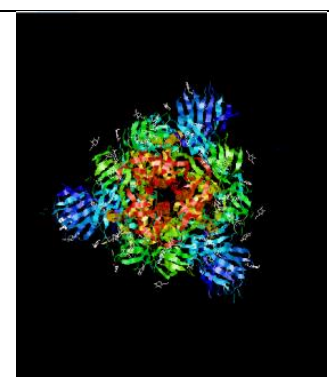

36. Tylophorine

Figure 1. Interactions between drug/compound and COVID-19 spike receptor.

Table 2. Interactions between drug/compound and COVID-19 spike receptor and scores are represented.

\begin{tabular}{|c|c|c|c|c|}
\hline S.No & Docked Compound name & Score & Area & ACE value \\
\hline 1 & Abacavir & 18958 & 2885.10 & -60.92 \\
\hline 2 & Acyclovir & 21434 & 4720.20 & 414.5 \\
\hline 3 & Anisomycin & 18698 & 2815.8 & -176.9 \\
\hline 4 & Azithromycin & 24910 & 3330.5 & 321.3 \\
\hline 5 & Cepharanthine & 3294 & 367.6 & -71.69 \\
\hline 6 & Chrysin & 21524 & 5339.9 & 75.39 \\
\hline 7 & Colchicine & 16134 & 2138.8 & -529.64 \\
\hline 8 & Cyanovirin & 22604 & 3792.4 & 381.34 \\
\hline 9 & Daidzin & 16358 & 3277.8 & 48.12 \\
\hline 10 & Emetine & 17140 & 2588.5 & 63.44 \\
\hline 11 & Emodine & 5254 & 667.2 & -601.74 \\
\hline 12 & Fangchinoline & 5476 & 628.2 & 365.45 \\
\hline 13 & Favipiravir & 24328 & 3166.3 & 465.16 \\
\hline 14 & Fingolimod & 4334 & 507.9 & -95.18 \\
\hline 15 & Ferruginol & 21628 & 3577.9 & -77.39 \\
\hline 16 & Hydroxychloroquine & 23918 & 3881.9 & 177.89 \\
\hline 17 & Interferon beta & 23262 & 5430.7 & 272.28 \\
\hline 18 & Ivermectin & 16940 & 2725.4 & 460.45 \\
\hline 19 & Kazinol & 4908 & 543.1 & -141.81 \\
\hline 20 & Lopinavir & 21358 & 3053.7 & 260.16 \\
\hline 21 & Luteolin & 3750 & 414.8 & -81.65 \\
\hline 22 & Marinostatin & 10132 & 1544.9 & 153.62 \\
\hline 23 & Mycophenolatemofetil & 3336 & 444.5 & -298.6 \\
\hline 24 & Oseltamivir & 21306 & 3317.7 & 188.66 \\
\hline 25 & Phenazopyridine & 4092 & 491.4 & -168.79 \\
\hline 26 & Quercetin & 20394 & 4099.8 & -534.64 \\
\hline 27 & Ribavirin & 19118 & 3306.8 & 460.45 \\
\hline 28 & Ritonavir & 22182 & 2990.2 & 426.74 \\
\hline 29 & Remedsivir & 19442 & 3019 & 207.83 \\
\hline 30 & Resveratrol & 18508 & 2706.8 & 30.92 \\
\hline 31 & Saikosaponins C & 6114 & 739.3 & -575.57 \\
\hline 32 & Saikosaponins D & 18964 & 2319.4 & -566.36 \\
\hline 33 & Silvestrol & 3744 & 398.3 & -214.69 \\
\hline 34 & Tannic acid & 20426 & 3756 & 158.23 \\
\hline 35 & Tanshinone & 3744 & 398.3 & -214.69 \\
\hline 36 & Tylophorine & 4702 & 598 & -289.23 \\
\hline 37 & Valganciclovir & 21666 & 3477.6 & 188.55 \\
\hline
\end{tabular}




\section{Conclusions}

To combat the pandemic novel coronavirus infection across the globe, several research and studies are on-going using pre-existing anti-viral activities. According to research, HIV proteases are found to be more potential in the treatment of COVID-19. In this current study, the Docking of 37 molecules of known anti-viral activity is studied. The HIV proteases of antiviral drugs showed remarkable strategy againstCOVID-19 disease. These 5 protease inhibitors, Abacavir, Cyanovirin, Lopinavir, Ritonavir, and Valganciclovir, are found to be practical. Azithromycin pursue translation of mRNA also convey a better activity in silico. In conjunction with these few new molecules/compounds as COVID-19 inhibits like Chrysin, Ferruginol, Quercetin, and Tannic acid. Ferruginol obstructs the growth of tumors against anti-tumor properties. It interacts with spike glycoprotein (PBD: 6M17) with a dock score value of 21628, respectively. Henceforth, we conclude from this study that the protease inhibitors are best reactive against COVID-19. Researchers can focus on untouched compounds that are found potential against COVID-19. These anti-viral drugs or compounds may furnish therapeutics in the future.

\section{Funding}

Ministry of Science and Technology, Department of Science and Technology (KIRAN Division) (GoI), New Delhi. (Ref No. DST/WOSB/ 2018/1583-HFN (G).

\section{Acknowledgments}

The authors gratefully acknowledge the Ministry of Science and Technology, Department of Science and Technology (KIRAN Division) (GoI), New Delhi. (Ref No. DST/WOSB/ 2018/1583-HFN (G)). The authors are also thankful to B.S. Abdur Rahman Institute of Science $\&$ Technology, Chennai, provides research facilities in the School of Life Sciences.

\section{Conflicts of Interest}

The authors declare no conflict of interest.

\section{References}

1. Stanley, P. Another decade, another coronavirus. $N$ Engl $J$ Med 2020, 382, 760-762, https://doi.org/10.1056/NEJMe2001126.

2. Abdo, A.E.; Noha, S. Anti-SARS and Anti-HCV Drugs Repurposing Against the Papain-like Protease of the Newly Emerged Coronavirus (2019-nCoV). Preprint 2020, https://doi.org/10.21203/rs.2.23280/v1.

3. Begum, S.M.F.; Priya, S.; Hemalatha, S. In vitro and In silico analysis of the Anti oxidant and Angiogenic potential of Padina tetrastomatica. Int. J. Pharmtech Res 2017, 10, 223-30.

4. Song, F.; Shi, N.; Shan, F.; Zhang, Z.; Shen, J.; Lu, H.; Ling, Y.; Jiang, Y.; Shi, Y. Emerging 2019 Novel Coronavirus (2019-nCoV) Pneumonia. Radiology 2020, 295, 210-217, https://doi.org/10.1148/radiol.2020200274.

5. Shah, B.; Modi, P.; Sagar, S.R. In silico studies on therapeutic agents for COVID-19: Drug repurposing approach. Life Sciences 2020, 252, https://doi.org/10.1016/j.lfs.2020.117652.

6. Alnajjar, R.; Mostafa, A.; Kandeil, A.; Al-Karmalawy, A.A. Molecular Docking, molecular dynamics, and in vitro studies reveal the potential of angiotensin II receptor blockers to inhibit the COVID-19 main protease. Heliyon 2020, 6, https://doi.org/10.1016/j.heliyon.2020.e05641.

7. $\quad$ van der Hoek, L.; Pyrc, K.; Jebbink, M.F.; Vermeulen-Oost, W.; Berkhout, R.J.M.; Wolthers, K.C.; Wertheim-van Dillen, P.M.E.; Kaandorp, J.; Spaargaren, J.; Berkhout, B. Identification of a new human coronavirus. Nature Medicine 2004, 10, 368-373, https://doi.org/10.1038/nm1024. 
8. Basit, A.; Ali, T.; Rehman, S.U. Truncated human angiotensin converting enzyme 2; a potential inhibitor of SARS-CoV-2 spike glycoprotein and potent COVID-19 therapeutic agent. Journal of Biomolecular Structure and Dynamics 2020, 1-10. https://doi.org/10.1080/07391102.2020.1768150.

9. Cascella, M.; Rajnik, M.; Cuomo, A.; Dulebohn, S.C.; Di Napoli, R. Features, Evaluation and Treatment Coronavirus (COVID-19). In: Stat Pearls. Treasure Island (FL): StatPearls Publishing. NBK554776, 2020.

10. Hanson, Q.M.; Wilson, K.M.; Shen, M.; Itkin, Z.; Eastman, R.T.; Shinn, P.; Hall, M.D. Targeting ACE2RBD Interaction as a Platform for COVID-19 Therapeutics: Development and Drug-Repurposing Screen of an AlphaLISA Proximity Assay. ACS Pharmacology \& Translational Science 2020, 3, 1352-1360, https://doi.org/10.1021/acsptsci.0c00161.

11. Deepti, C.; Jaspreet, K.B.; Bharti, B.; Anurag, S.; Rakesh, G. Pharmacological strategies for COVID-19 - A review of the most promising repurposed anti-viral drugs. Infectious Disorders - Drug Targets 2020, 20, 112, https://doi.org/10.2174/1871526520666201218151841.

12. Hussain, I.; Hussain, A.; Alajmi, M.F.; Rehman, M.T.; Amir, S. Impact of repurposed drugs on the symptomatic COVID-19 patients. Journal of Infection and Public Health 2021, 14, 24-38, https://doi.org/10.1016/j.jiph.2020.11.009.

13. Kandeel, M.; Kitade, Y.; Almubarak, A. Repurposing FDA-approved phytomedicines, natural products, antivirals and cell protectives against SARS-CoV-2 (COVID-19) RNA-dependent RNA polymerase. PeerJ 2020, 8, https://doi.org/10.7717/peerj.10480.

14. Sayed, A.M.; Khalaf, A.M.; Abdelrahim, M.E.A.; Elgendy, M.O. Repurposing of some anti-infective drugs for COVID-19 treatment: A surveillance study supported by an in silico investigation. International Journal of Clinical Practice 2020, 9, https://doi.org/10.1111/ijcp.13877.

15. Gralinski, L.E.; Menachery, V.D. Return of the Coronavirus: 2019-nCoV. Viruses 2020, 12, https://doi.org/10.3390/v12020135.

16. Cui, W.; Yang, K.; Yang, H. Recent Progress in the Drug Development Targeting SARS-CoV-2 Main Protease as Treatment for COVID-19. Frontiers in Molecular Biosciences 2020, 7, https://doi.org/10.3389/fmolb.2020.616341.

17. Praveen Thaggikuppe, K. Coronavirus Disease 2019: Virology and Drug Targets. Infectious Disorders Drug Targets 2021, 21, 1-8, https://doi.org/10.2174/1871526520666201209145302.

18. Elfiky, A.A. Anti-HCV, nucleotide inhibitors, repurposing against COVID-19. Life Sciences 2020, 248, https://doi.org/10.1016/j.lfs.2020.117477.

19. Puhl, A.C.; Fritch, E.J.; Lane, T.R.; Tse, L.V.; Yount, B.L.; Sacramento, C.Q.; Tavella, T.A.; Costa, F.T.M.; Weston, S.; Logue, J.; Frieman, M.; Premkumar, L.; Pearce, K.H.; Hurst, B.L.; Andrade, C.H.; Levi, J.A.; Johnson, N.J.; Kisthardt, S.C.; Scholle, F.; Souza, T.M.L.; Moorman, N.J.; Baric, R.S.; Madrid, P.; Ekins, S. Repurposing the Ebola and Marburg Virus Inhibitors Tilorone, Quinacrine and Pyronaridine: In vitro Activity Against SARS-CoV-2 and Potential Mechanisms. bioRxiv 2020, 2, https://doi.org/10.1101/2020.12.01.407361.

20. Gurung, A.B.; Ali, M.A.; Lee, J.; Farah, M.A.; Al-Anazi, K.M. The potential of Paritaprevir and Emetine as inhibitors of SARS-CoV-2 RdRp. Saudi Journal of Biological Sciences 2021, 28, 1426-1432, https://doi.org/10.1016/j.sjbs.2020.11.078.

21. Chen, Y.; Liu, Q.; Guo, D. Emerging coronaviruses: Genome structure, replication, and pathogenesis. Journal of Medical Virology 2020, 92, 418-423, https://doi.org/10.1002/jmv.25681.

22. Priya, S.; Kumar, N.S.; Hemalatha, S. Antiviral phytocompounds target envelop protein to control Zika virus. Comput Biol Chem 2018, 77, 402-412, https://doi.org/10.1016/j.compbiolchem.2018.08.008.

23. Chugh, H.; Awasthi, A.; Agarwal, Y.; Gaur, R.K.; Dhawan, G.; Chandra, R. A comprehensive review on potential therapeutics interventions for COVID-19. European Journal of Pharmacology 2021, 890, https://doi.org/10.1016/j.ejphar.2020.173741.

24. Baby, K.; Maity, S.; Mehta, C.H.; Suresh, A.; Nayak, U.Y.; Nayak, Y. Targeting SARS-CoV-2 RNAdependent RNA polymerase: An in silico drug repurposing for COVID-19. F1000Res 2020, 23, https://doi.org/10.12688/f1000research.26359.1.

25. Arpudhamary, V.; Priya, S.; Manzoor, M.A.P.; Mubarakali, D.; Hemalatha, S. Apoptotic-inducing factor 1 (AIF1) plays a critical role in cembranoid mediated apoptosis to control cancer: Molecular docking and dynamics study. Biocatalysis and Agricultural Biotechnology 2019, 22, https://doi.org/10.1016/j.bcab.2019.101343.

26. Wang, M.; Cao, R.; Zhang, L.; Yang, X.; Liu, J.; Xu, M.; Shi, Z.; Hu, Z.; Zhong, W.; Xiao, G. Remdesivir and chloroquine effectively inhibit the recently emerged novel coronavirus (2019-nCoV) in vitro. Cell Research 2020, 30, 269-271, https://doi.org/10.1038/s41422-020-0282-0.

27. Liu, X.; Wang, X.-J. Potential inhibitors against 2019-nCoV coronavirus M protease from clinically approved medicines. Journal of Genetics and Genomics 2020, 47, 119-121, https://doi.org/10.1016/j.jgg.2020.02.001.

28. Behera, S.K.; Mahapatra, N.; Tripathy, C.S.; Pati, S. Drug repurposing for identification of potential inhibitors against SARS-CoV-2 spike receptor-binding domain: An in silico approach. The Indian journal of medical research 2020, 7, https://doi.org/10.4103/ijmr.IJMR_1132_20. 
29. Lutfiya, A.S.; Priya, S.; Manzoor, M.A.P.; Hemalatha, S. Molecular docking and interactions between vascular endothelial growth factor (VEGF) receptors and phytochemicals: An in-silico study. Biocatalysis and Agricultural Biotechnology 2019, 22, https://doi.org/10.1016/j.bcab.2019.101424.

30. Drożdżal, S.; Rosik, J.; Lechowicz, K.; Machaj, F.; Kotfis, K.; Ghavami, S.; Łos, M.J. FDA approved drugs with pharmacotherapeutic potential for SARS-CoV-2 (COVID-19) therapy. Drug Resistance Updates 2020, 53, https://doi.org/10.1016/j.drup.2020.100719.

31. Verma, A.K.; Aggarwal, R. Repurposing potential of FDA-approved and investigational drugs for COVID19 targeting SARS-CoV-2 spike and main protease and validation by machine learning algorithm. Chemical Biology \& Drug Design 2020, 7, https://doi.org/10.1111/cbdd.13812.

32. Watashi, K. Identifying and repurposing anti-viral drugs against severe acute respiratory syndrome coronavirus 2 with in silico and in vitro approaches. Biochemical and Biophysical Research Communications 2020, 20, https://doi.org/10.1016/j.bbrc.2020.10.094.

33. Mohamed, K.; Yazdanpanah, N.; Saghazadeh, A.; Rezaei, N. Computational drug discovery and repurposing for the treatment of COVID-19: A systematic review. Bioorganic Chemistry 2021, 106, https://doi.org/10.1016/j.bioorg.2020.104490.

34. Singh, R.K.; Yadav, B.S.; Mohapatra, T.M. Molecular targets and system biology approaches for drug repurposing against SARS-CoV-2. Bulletin of the National Research Centre 2020, 44, https://doi.org/10.1186/s42269-020-00444-3.

35. Gimeno, A.; Mestres-Truyol, J.; Ojeda-Montes, M.J.; Macip, G.; Saldivar-Espinoza, B.; Cereto-Massagué, A.; Pujadas, G.; Garcia-Vallvé, S. Prediction of Novel Inhibitors of the Main Protease (M-pro) of SARSCoV-2 through Consensus Docking and Drug Reposition. International Journal of Molecular Sciences 2020, 21, https://doi.org/10.3390/ijms21113793.

36. Sabiha Sulthana, H.B.; Ranjani, S.; Hemalatha S. Comparison of efficacy of nanoparticles synthesized from leaves and flowers of Russelia equisitiformis. Inorganic and Nano-Metal Chemistry 2020, https://doi.org/10.1080/24701556.2020.1862218.

37. Yousefi, H.; Mashouri, L.; Okpechi, S.C.; Alahari, N.; Alahari, S.K. Repurposing existing drugs for the treatment of COVID-19/SARS-CoV-2 infection: A review describing drug mechanisms of action. Biochemical Pharmacology 2021, 183, https://doi.org/10.1016/j.bcp.2020.114296.

38. Nagoor Meeran, M.F.; Sharma, C.; Goyal, S.N.; Kumar, S.; Ojha, S. CB2 receptor-selective agonists as candidates for targeting infection, inflammation, and immunity in SARS-CoV-2 infections. Drug Development Research 2021, 82, 7-11, https://doi.org/10.1002/ddr.21752.

39. Sai Nivetha, S.; Ranjani, S.; Hemalatha, S. Synthesis and application of silver nanoparticles using Cissus quadrangularis. Inorganic and Nano-Metal Chemistry 2020, https://doi.org/10.1080/24701556.2020.1862219.

40. Odhar, H.A.; Ahjel, S.W.; Albeer, A.A.M.A.; Hashim, A.F.; Rayshan, A.M.; Humadi, S.S. Molecular docking and dynamics simulation of FDA approved drugs with the main protease from 2019 novel coronavirus. Bioinformation 2020, 16, 236-244, https://doi.org/10.6026/97320630016236.

41. Yu, R.; Chen, L.; Lan, R.; Shen, R.; Li, P. Computational screening of antagonists against the SARS-CoV2 (COVID-19) coronavirus by molecular Docking. International Journal of Antimicrobial Agents 2020, 56, https://doi.org/10.1016/j.ijantimicag.2020.106012.

42. Elmezayen, A.D.; Al-Obaidi, A.; Şahin, A.T.; Yelekçi, K. Drug repurposing for coronavirus (COVID-19): in silico screening of known drugs against coronavirus 3CL hydrolase and protease enzymes. Journal of Biomolecular Structure and Dynamics 2020, 38, 1-13, https://doi.org/10.1080/07391102.2020.1758791.

43. Peele, K.A.; Potla Durthi, C.; Srihansa, T.; Krupanidhi, S.; Ayyagari, V.S.; Babu, D.J.; Indira, M.; Reddy, A.R.; Venkateswarulu, T.C. Molecular Docking and dynamic simulations for anti-viral compounds against SARS-CoV-2: A computational study. Informatics in Medicine Unlocked 2020, 19, https://doi.org/10.1016/j.imu.2020.100345.

44. Zhang, D.-H.; Wu, K.-L.; Zhang, X.; Deng, S.-Q.; Peng, B. In silico screening of Chinese herbal medicines with the potential to directly inhibit 2019 novel coronavirus. Journal of Integrative Medicine 2020, 18, 152158, https://doi.org/10.1016/j.joim.2020.02.005. 